KS. ZDZISŁAW KROPIDŁOWSKI* - BYDGOSZCZ

\title{
IWO ROHWEDER JAKO BUDOWNICZY KOŚCIOŁA I DUSZPASTERZ PARAFII W LĘGOWIE
}

Parafia w Łęgowie pod wezwaniem św. Mikołaja Biskupa została prawdopodobnie erygowana w XIV w. Położona była 25 mil od stolicy biskupstwa we Włocławku, należała do diecezji włocławskiej i pomorskiej, leżała w archidiakonacie pomorskim i dekanacie gdańskim. Patronat nad nią sprawowali opaci oliwscy, który przedstawiali biskupom kandydatów na proboszczów. Nie zawsze byli nimi cystersi oliwscy.

Za przykład może służyć ks. Karol Stanisław Boryszewski, pochodzący z Kaszub, który został instytułowany na plebana w Łęgowie 2 kwietnia 1737 r. Data jego urodzin jest nieznana. Pod koniec sierpnia 1731 r. ukończył kurs filozofii w seminarium jezuickim w Szkotach Gdańskich. Jego nazwisko pojawia się w aktach konsystorza gdańskiego 11 grudnia 1734 r., kiedy to otrzymał prowizję na wikariat w Różynach od proboszcza ks. Andrzeja Reussa. Przez dwa lata, od marca 1735 r. do kwietnia 1737 r. pracował jako wikariusz w Kłodawie, a 2 kwietnia tegoż roku został mianowany proboszczem w Łęgowie. Swoje beneficjum objął kanonicznie 11 kwietnia 1737 r. w obecności ks. Adama Zaręby, plebana kłodawskiego, ks. Jakuba Fischera, instygatora konsystorza gdańskiego i ks. Marcina Kilau a, komendatariusza łęgowskiego. W 1741 r. administrował także parafią w Różynach. Jesienią $1741 \mathrm{r}$. został prezentowany przez jezuitów na probostwo w Gemlicach, które objął 25 października dzięki decyzji bpa włocławskiego Adama Grabowskiego. Tam zmarł w lutym lub marcu 1758 r. ${ }^{1}$

W Archiwum Parafialnym w Lęgowie zachowała się księga zawierająca odpisy wizytacji, przywilejów i protokołów dotyczących parafii zawierająca m. in. opis świątyni i dóbr parafialnych, które przejął we władanie o. Iwo Rohweder 13 listopada 1741 r. Objęcie parafii odbyło się komisyjnie z udziałem ks. K. S. Boryszewskiego, o. I. Rohwedera, o. Gabriela Rudolfa, cystersa i wikariusza łęgowskiego i parafii w Różynach².

* Ks. Zdzisław Kropidłowski - dr hab. historii, prof. Uniwersytetu Kazimierza Wielkiego w Bydgoszczy.

${ }^{1}$ T. Nowicki, Słownik biograficzny rządców parafii archidiakonatu pomorskiego $w$ XVIII wieku, Lublin 2003, s. 46-47.

${ }^{2}$ Archiwum Parafii w Łęgowie [dalej: APŁ], Chronika Parochia Łęgowo, t. I, s. 183. 
Zapis ten pozwala na ustalenie stanu kościoła i jego dóbr w momencie przybycia o. Iwo Rohwedera do Łęgowa oraz jego dokonań, ponieważ zaraz po jego śmierci odbyła się wizytacja generalna dekanatu gdańskiego przeprowadzona przez ks. Bartłomieja Trochowskiego, który w dniu 15 listopada 1765 r. odwiedził Łęgowo i Różyny, wizytując obie parafie.

W protokole wizytacji odnotował on, że wszystko co dobre znajduje się w świątyni i zabudowaniach parafialnych jest dziełem I. Rohwedera, tymczasem tak nie było. Ks. K. S. Boryszewski zostawił kościół murowany, z murowaną dzwonnicą i zakrystią. Ten opis kościoła jest powierzchowny, ale możemy nieco powiedzieć o jego stanie. Był on wymurowany z cegieł, ale miał ,pieknięcie-rozciecie”. Zamknięcie miały stanowić nowe drzwi, wykonane z drewna sosnowego i pomalowane na zielono, ale nie posiadały jeszcze zawiasów i zamka. Krużganek i portyk kościoła przeznaczony dla ubogich nie miał jeszcze sklepienia. Były w nim trzy „nierówne” okna większe i dwa mniejsze „po większej części całe”.

Na dzwonnicy wisiały 2 dzwony, a trzeci mały zwany „sygnarkiem” nad prezbiterium. Na dzwonnicy był zegar, ale chodzący „według własnej miary” wybijający godziny. Na chórze stał pozytyw, czyli małe organy. Ołtarz główny wykonany był z murowanych cegieł, a nastawa była rzeźbiona (prawdopodobnie przeniesiona z późniejszej kaplicy seminaryjnej Katedry Oliwskiej), ozdobiona malowidłami pozłacanymi i posrebrzanymi. Na pierwszym piętrze znajdował się wizerunek Matki Bożej Wniebowziętej, powyżej Trójcy Świętej. Z lewej strony ołtarza głównego stała mała szafa do przechowywania monstrancji. Przed ołtarzem główny stały dwa rzędy ław chóralnych, zapewne służących za miejsce dla witrykusów i służby kościelnej. Były na nich „dawno” wymalowane wizerunki świętych.

Przed nimi ustawiono po prawej stronie ołtarz boczny mniejszy, ozdobiony świeżo złotem i srebrem oraz malowidłami. W centrum ołtarza umieszczony był wizerunek-rzeźba Chrystusa Ukrzyżowanego, a nad nim obraz św. Wawrzyńca Męczennika.

Na środku kościoła stały 2 rzędy ław „,dość godnych”. Pod chórem była skarbona, do której od wielu lat nie można znaleźć było klucza. Kropielnica ustawiona przy wejściu była wykonana $\mathrm{z}$ wydrążonego kamienia, a podobna, ale rozbita, stała przed wejściem do kościoła, przed dzwonnicą.

Ambona była stara, wykonana z desek, ale miała „piękne malowidło”. Obrazów w kościele było 16. W zakrystii przechowywano obraz św. Mikołaja Biskupa, namalowany „niedawno" z gałązką, prawdopodobnie oliwnąa oraz baldachim kwadratowy, donoszenia przez4 mężczyzn, wykonanyzmalowanego drewnai przyozdobiony zwisającymi frędzlami z jedwabiu, który był już znacznie uszkodzony. Znajdował się tam również feretron, rzeźbiony, malowany i pozłacany $\mathrm{z}$,gałązką" zawierający wizerunek Najświętszej Marii Panny z Jezusem. Matka Boża miała na głowie koronę srebrną, w ręku srebrne i pozłacane berło, a Dzieciątko koronę i szatę całą ze srebra. Po drugiej stronie były również wizerunki Marii i Chrystusa ze srebrnymi koronami, ale jeszcze były przyozdobione srebrnymi

\footnotetext{
${ }^{3}$ Tamże, s. 175.

${ }^{4}$ Tamże, s. 176.
} 
promieniami. Feretron był zwieńczony drewnianą koroną, nad którą umieszczono srebrne jabłko z krzyżem. Miał on jeszcze jakieś inne ozdoby wykonane ze srebra, a umieszczone na bokach ${ }^{5}$. Wizerunki na feretronie były zasłaniane jedwabnymi zasłonami, dwie były koloru czerwonego, a dwie koloru białego ${ }^{6}$.

O zabudowaniach parafialnych wizytator podał, że „nie są godne opisania”. Plebania , $\mathrm{z}$ trudem nosiła ślady godnego i stosownego budynku, $\mathrm{z}$ trudem można

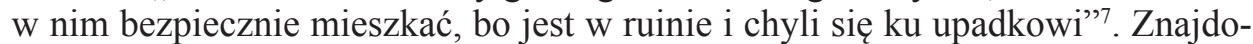
wał się w niej jeden stół z marmurowym blatem - dobry, dwie ławy, trzy stare krzesła, które stały w głównej izbie, „,szczególnie ciemnej”, choć oświetlały ją dwa okna dość dobre. Piec był wypalony ze starości, a spiżarnia niewielka. Stajnia była jedna, ale nie nadawała się do użytku, dlatego prawdopodobnie (bo nie zostało to odnotowane) nie było w niej ani koni, ni inwentarza żywego, a w spichrzu zboża ${ }^{8}$.

Ks. K.S. Boryszewski nie był cystersem, co mogło być powodem odwołania go ze stanowiska w Łęgowie, z parafii którą cystersi oliwscy ufundowali i się nią opiekowali. Innym powodem mogło być niezadowolenie władz zakonnych z jego pracy duszpasterskiej i administracyjnej. W źródłach znajdujemy bowiem w tym czasie ślady narzekania duchowieństwa zakonnego, głównie cystersów i jezuitów na duchowieństwo diecezjalne, któremu zarzucano brak gorliwości duszpasterskiej. Opis świątyni z $1741 \mathrm{r}$. oraz wcześniejszy z wizytacji dokonanej przez archidiakona Józefa Ignacego Narzymskiego w 1729 r. ${ }^{10}$ wynika, że świątynia i zabudowania parafialne ulegały stopniowemu niszczeniu i domagały się dobrego gospodarza, który by odnowił dawną świetność kościoła i parafii.

Być może z tego powodu o. Iwo Rohweder do swoich licznych obowiązków zakonnych postanowił dodać jeszcze funkcję proboszcza w Lęgowie. Musiał na to uzyskać zgodę opata Jacka Rybińskiego i ordynariusza bpa Walentego Aleksandra Czapskiego. Parafia ta w 1741 r. nie była wielka ani ważna. Liczyła 786 katolików i 165 innowierców, którzy mieszkali w Łęgowie, Skowarczu i Grabinie. Różyny były już od dhugiego czasu parafią filialną, razem mieszkało w 1765 r. w obu parafiach 905 katolików $^{11}$.

Łęgowo nie było też parafią zamożną, bo beneficjum proboszczowskie stanowiły tylko 2 łany (ok. 50 ha) gruntów ornych i łąk z nadania cystersów, choć przez wieki również chłopi dodawali kawałki gruntów ornych, które zapisywali na rzecz parafii. Na gruntach kościelnych wysiewano 32 korce zbóż, głównie pszenicy. Chłopi mieli obowiązek je uprawiać, ale ta „pańszczyna” nie była trudna, stanowiła tylko pracę w czasie żniw jeden dzień w roku z sierpem i w innym czasie dwa dni pługiem. Zgodnie też z prawem państwowym otrzymywał dziesięcinę, ale

\footnotetext{
${ }^{5}$ Tamże s. 177.

${ }^{6}$ Tamże, s. 178.

${ }^{7}$ Tamże, s. 182.

${ }^{8}$ Tamże, s. 183.

${ }^{9}$ ADCh. G-42 s. 48; Z. Kropidłowski, Kongregacje w dekanacie puckim na podstawie księgi z lat 1728-1779, „Studia Gdańskie”, 26 (2010) s. 206.

${ }^{10}$ APŁ, Chronika, s. 162-168.

${ }^{11}$ Archiwum Diecezji Chełmińskiej w Pelplinie [dalej: ADCh], G. 71, k. 333 i k. 374.
} 
w niepełnym wymiarze, bo tylko 47 korców pszenicy i tyleż owsa, opłatę na zakup drewna opałowego w wysokości 17 florenów rocznie. Tyle samo na kolędę. Ciekawostką jest to, że od każdego gbura, jak nazywano na Pomorzu kmieci, pobierał 15 główek kapusty, a na Wielkanoc po 15 jaj i pierwszy chleb z każdego chłopskiego wypieku. Ze wsi Grabiny, zamieszkałej w większej części przez protestantów, otrzymywał 24 korce jęczmienia albo w zamian 30 florenów, a na kolędę jaja, jarzyny i 36 florenów. Od mieszkańców wsi Skowarcz jako daninę otrzymywał 20 korców pszenicy i 20 korców owsa, na drewno opałowe po 8 florenów rocznie, na kolędę 16 florenów i 18 groszy, również chleby z wypieków, 15 jaj i tyle samo kapusty od każdego gospodarza.

Dochody te nie były wysokie. Dla porównania można podać, że dochody proboszczów w parafii cysterskiej w Starzynie wynosiły po 66 korców pszenicy i tyleż owsa, na kolędę 41 florenów oraz inne opłaty, a parafia była znacznie mniejsza bo liczyła 625 osób $^{12}$. Jeszcze gorzej wypadało Łęgowo w porównaniu z parafią w Mechowie, gdzie w 1742 r. opat oliwski Jacek Rybiński wzniósł kościół i go wyposażył w 5 ołtarzy, rzeźbionych, posrebrzanych i pozłacanych oraz we wszystkie inne sprzęty ${ }^{13}$. Zabudowania gospodarcze odnowił ówczesny proboszcz, cysters o. Dionizy Grosmann. Dochody jego były znacznie większe niż w Łęgowie. Wynosiły bowiem 95 korców pszenicy i 92 korce owsa oraz 80 florenów z tytułu różnych ofiar, a parafia liczyła 636 katolików, 32 luteran i 18 kalwinów. Beneficjum było większe, bo wynosiło 4 włóki gruntów ornych (ok. 100 ha) i łąki ${ }^{14}$.

Objęcie parafii przez o. Iwo Rohwedera należy więc łączyć z powodami duszpasterskimi, a nie materialnymi. Porównanie parafii w Łęgowie i parafii w Mechowie nie jest przypadkowe. Bowiem w tym samym czasie opat J. Rybiński w Mechowie wzniósł nowy kościół i go wyposażył, a przeor Iwo Rohweder uczynił to w Łęgowie. Na wzniesienie dwóch świątyń w Łęgowie i Różynach potrzeba było oczywiście uzyskać zgodę opata i zapewnić znaczne finansowanie przedsięwzięcia. Uczynił to - jak wielu kapłanów - z majątku własnego. Dlatego można przypuszczać, że traktował te parafie jako swoje szczególne dzieła życia, które zgodnie z duchowością baroku, miały świadczyć o jego religijności przed sądem Bożym po śmierci.

O. Iwo Rohweder wzniósł w Łęgowie praktycznie nowy kościół, wyposażył go w cenne sprzęty i paramenty liturgiczne, niezbędne do sprawowania kultu, wzniósł nową plebanię, przytułek dla biednych, 9 chałup czynszowych i zabudowania gospodarcze. Wyróżnił się również troską religijną o swoich parafian. Ponieważ obowiązki przeora klasztoru nie pozwalały mu na stałe rezydować w parafii, ufundował etat wikariusza, który zastępował go w pracy duszpasterskiej i w należytym sprawowaniu kultu, troszczył się o dwa bractwa dewocyjne i działalność dobroczynną ${ }^{15}$.

${ }^{12}$ Z. Kropidłowski, Dobra materialne, wyposażenie i dochody parafii, duchowieństwa i stużby kościelnej dekanatu puckiego w okresie staropolskim, Gdańsk 2007, s. 151.

${ }^{13}$ Tamże, s. 161.

${ }^{14}$ Tamże, s. 157 i 165.

${ }^{15}$ ADCh, G-71, k. 375v; Z. Kropidłowski, Parafia w Łęgowie w II połowie XVIII wieku, w: Z potrzeby serca, red. Z. Krzyszowski, M. Nowak i S. Sieczko, Lublin 2004, s. 243. 
Jego gorliwość została dostrzeżona przez bpa A. Czapskiego, który odpowiadając na prośbę I. Rohwedera o konsekrację kościoła po jego wzniesieniu, upoważnił go specjalnym dekretem podpisanym w Gdańsku 18 listopada 1748 r. do (prawdopodobnie) jej konsekracji ,według rytuału rzymskiego. Msza święta niech zostanie odprawiona przez Ciebie - pisał - i innych prezbiterów, o ile nie są tułaczami, ekskomunikowani albo pozbawieni swoich praw z powodu nie odprawienia rekolekcji, na portatylu należycie konsekrowanym, ozdobionym, przy zapalonych świecach. Dalej wymagał - niech zostanie wygłoszone słowo Boże, niech zostaną udzielone sakramenty żywym i zmarłym [?] w Chrystusie, niech zostaną odprawione procesje publiczne oraz wszystkie inne sprawy zgodne z prawem". Biskup usprawiedliwiał się przy tym, że jest bardzo zajęty trudnościami państwa i diecezji. Było to wielkie wyróżnienie, bo poświęcenie kościoła, a jeszcze bardziej jego konsekracja, była zastrzeżona biskupom.

Pracę budowniczego rozpoczął od wzniesienia nowej świątyni. Stary kościół, choć wzniesiony był z cegły i kryty dachówką, popękał i zapewne był zbyt mały do potrzeb. Prace budowlane i wykończeniowe trwały od 1743 do 1748 r. Przez następne dwa lata pobudował budynki plebańskie i gospodarcze.

Swiątynia została wzniesiona $\mathrm{z}$ cegiel, na nowych fundamentach i w nowym kształcie krzyża łacińskiego. Budowlę pokrył dachówkami ceramicznymi, a wieżę blachami z ołowiu. Dzwonnica została posadowiona u wejścia do kościoła z pruskiego muru, na której powiesił dwa stare dzwony, średniej wielkości. Większy był wysoki na 1 i 3/4 łokcia o średnicy 4 i 1 1/2 łokcia, mniejszy był wysoki na 1 i $1 \frac{1}{4}$ łokcia i miał średnicę 3 łokcie. Na małej wieży, nad prezbiterium, zamontował dawny mały dzwon zwany sygnarkiem, który wzywał wiernych na nabożeństwa różańcowe i dawał znak, że kapłan wychodził z kościoła do chorego w sposób uroczysty, czyli pod baldachimem.

Na dzwonnicy kazał na nowo zamontować stary zegar, w którym na koszt parafian naprawiono kółka i zaopatrzono w trzy pozłacane wskazówki.

Do kościoła domurował zakrystię na nowym miejscu, za ołtarzem głównym, a na północnej stronie cmentarza wzniósł kostnicę z pruskiego muru.

Architekturę świątyni przyozdobił kilkoma figurami. Na fasadzie, od strony drogi publicznej, umieścił pięć wielkich dębowych i pozłacanych figur, które przedstawiały Najświętszą Maryję Pannę, św. Mikołaja Biskupa Wyznawcę - patrona parafii, św. Wawrzyńca Męczennika, św. Bernarda i św. Jana Nepomucena Męczennika. Ponad przednim krużgankiem ustawił figurę Dobrego Pasterza z dwoma patronami parafii, św. Mikołajem, trzymającym mitrę i księgę oraz ze św. Wawrzyńcem z krzyżem i kielichem. Pomiędzy nimi, na środku fasady, powiesił „wyjątkowy, pozłacany duży krucyfiks”. Na fasadach naw bocznych umieścił również figury wykonane $\mathrm{z}$ dębu. Jedna przedstawiała Matkę Bożą Niepokalanie Poczętą, a druga Matkę Bożą Bolesną. Ponad nimi zawiesił jeszcze figurki aniołów w locie, trzymających w dłoniach po dwa koła płonące z imionami Jezusa i Marii. Te postacie też zostały pozłocone. Natomiast na fasadzie nad zakrystią umieścił posągi św. Józefa, żywiciela Jezusa, św. Anny i św. Barbary. Były one też wykonane $\mathrm{z}$ dębu i pozłocone.

Ze wszystkich stron kościoła, na cmentarzu, posadził drzewa oliwne, na któ- 
rych zwiesił małe wizerunki Najświętszej Marii Panny wykonane z żelaza i pozłacane $^{16}$.

$\mathrm{Z}$ opisu tego wynika, że budowla ta wyglądał bardzo solidnie, a przyozdobienie jej wieloma pozłacanymi figurami sprawiało wrażenie dużego bogactwa parafii i jej mieszkańców.

Swiątynię otaczał cmentarz, ogrodzony murem, który z powodu naporu gruntu ciągle trzeba było konserwować. Za poprzednika I. Rohwedera mur ten podupadł i nie chronił cmentarza przed zwierzętami, które do niego wchodziły, on więc ogrodził go solidnym murem zawierającym cegły odprowadzające wodę deszczową. Parafianie, wyznawcy innych religii niż katolicka, mieli swoją część, przeznaczoną na własny cmentarz, który również przylegał do budynku kościoła. I. Rohweder, jako proboszcz, był zobowiązany prowadzić ich księgi metrykalne, odnotowywać chrzciny, śluby i zgony, za co pobierał opłaty wyznaczone w taksie za posługi duszpasterskie ${ }^{17}$. Z prawa państwowego musieli oni składać ofiary jak katolicy, w tym samym wymiarze i wysokości, choć najczęściej się od tego uchylali lub je pomniejszali. Wydzielenie im w Łęgowie miejsca na grzebanie zmarłych na cmentarzu katolickim było wyrazem zgodnego współżycia różnych wyznań.

O. I. Rohweder ustawił w kościele cztery ołtarze. Czytając tylko relację wizytatora ks. B. Trochowskiego, wydaje się, że wszystkie były nowe, ale przynajmniej ołtarz główny i ołtarz Ukrzyżowania zostały wykorzystane ze starej świątyni. Podobnie jest ze wszelkimi innymi paramentami przeznaczonymi na sprawowanie kultu.

Zapewne mensy ołtarzowe zostały na nowo wymurowane, a stare nastawy częściowo wykorzystane. Na mensach umieścił nowe portatyle, wykonane starannie i konsekrowane. Pięknem wyróżnia się ołtarz główny zachowany do dziś. Ma trzy kondygnacje wykonane $\mathrm{z}$ drewna, pozłacane, posrebrzane i malowane, $\mathrm{z}$ wieloma elementami ozdobnymi. Mensy czterech ołtarzy były przykryte trzema obrusami długimi, zwisającymi po bokach do samej podstawy ołtarzy. Na głównym ołtarzu ina Ołtarzu Najświętszej Marii Panny stało na świecznikach po 6 świec, na pozostałych po 4.

Na pierwszej kondygnacji ołtarza głównego kazał umieścić dwa wizerunki. Pierwszy przedstawiający Dobrego Pasterza i przyozdobić go srebrnymi i pozłacanymi promieniami dookoła głowy. Drugi przedstawiał postać Melchizedeka przy stole ofiarnym, jako prototyp Chrystusa, którego postać nakazał pokryć blachą mosiężną i pozłacaną.

Na wyższej kondygnacji umieścił obraz Trójcy Świętej, przyozdobionej srebrnymi koronami, a po bokach umieścił dawne wota wykonane ze spiżu, pochodzące z dawnej świątyni. Na najwyższej kondygnacji umieścił obraz Matki Bożej namalowany na wzór wizerunku z Rokitna, której nałożył na głowę koronę i ubrał w szatę mosiężną pozłacaną i posrebrzaną z białym orłem na piersi.

$\mathrm{Na}$ mensie ołtarza ustawił solidne drewniane tabernakulum zaopatrzone

${ }^{16}$ Tamże, k. 368v.

${ }^{17}$ Por. Z. Kropidłowski, Taksa za postugi duszpasterskie $w$ archidiakonacie pomorskim $w$ XVIIXVIII w., „Studia Gdańskie”, 15-16 (2002-2003) ss. 65-73. 
w mocny zamek i przyozdobione czterema figurami, o których na jednym miejscu napisano, że były pozłacane, a na innym miejscu, że posrebrzane ${ }^{18}$.

W kaplicy św. Bernarda ustawił dwa ołtarze. Pierwszy poświęcony św. Bernardowi, patronowi cystersów, który jest namalowany w ornacie i przyozdobiony promieniami wykonanymi z blachy mosiężnej ${ }^{19}$. Został on przeniesiony z Oliwy i zestawiony $\mathrm{z}$ różnych elementów w $1751 \mathrm{r}$. Na obrazie głównym został przedstawiony święty, który trzyma Najświętszy Sakrament i zwraca się do księcia Wilhelma Akwitańskiego, aby nawrócił się ze schizmy. W zwieńczeniu umieszczony jest owalny obraz Chrystusa ukazującego swoje rany, który jest wcześniejszy, bo pochodzi z pierwszej ćwierci XVII w. ${ }^{20}$ Poniżej tego ołtarza nakazał wykonać schowek dobrze zamknięty, służący do przechowywania sreber parafialnych, zaopatrzony w sekretne zamki z wielkimi kluczami.

$\mathrm{Z}$ boku tego ołtarza ustawił nowy konfesjonał. Drugi ołtarz przedstawiający Ukrzyżowanie został już wcześniej ofiarowany przez klasztor oliwski. Ponieważ lud czcił ten ołtarz z wielką pobożnością, o. Iwo przyozdobił go ku większej chwale Ukrzyżowanego lśniącymi, czerwonymi zasłonami, a sam krzyż pozłacanymi blaszkami, czerwonymi kamieniami i promieniami. Na głowę Jezusa nałożył koronę królewską, pozłacaną i posrebrzaną, upiększoną czeskimi klejnotami. Stały tu relikwie Krzyża św., o których będzie jeszcze mowa. Przed tym ołtarzem powiesił lampę wieczną posrebrzaną, a na środku nawy mosiężny posrebrzany żyrandol.

W nawie tej o. Iwo ustawił również ołtarz bractwa różańcowego, przy którym odprawiano msze wotywne do Matki Bożej (dlatego nawę tę nazwano również kaplicą różańcową). W jego nastawie znajdowało się aż dziewięć posągów (dzisiaj jest tylko siedem) pozłacanych i cztery kolumny. W pierwszej kondygnacji umieścił dwa obrazy. Pierwszy św. Dominika, w srebrnych i pozłacanych szatach, który adoruje Maryję w szacie z czystego srebra, częściowo pozłoconą i Jezusa przybranego w srebrną szatę, którzy są przedstawieni na owalnym, drugim obrazie, wśród aniołów również przyozdobionych srebrem.

Na drugiej kondygnacji kazał namalować wizerunek Pana Jezusa, pokrytego sukienką pozłacaną. Na trzeciej był obraz Niepokalanego Poczęcia Najświętszej Marii Panny mającej szaty i płaszcz z mosiądzu, pozłacany i posrebrzany, z promieniami. Na szczycie ołtarza postawił figurę św. Kazimierza Królewicza. Ołtarz ten został wyposażony w cztery cynowe świeczniki i wiszący, mosiężny żyrandol.

W ramach pracy duszpasterskiej trzeba podkreślić starania o. Iwo, o założenie bractwa różańcowego, bo zabiegał o to nawet w Rzymie. Dokument erekcyjny został wystawiony przez Tomasza Ripolię, magistra Zakonu Kaznodziejskiego i Emeryka Langewaltera, magistra, w którym ustanowiono powołanie bractwa i określono zasady jego działania już 12 marca 1750 r. Zgodnie z nim bractwo różańcowe zostało w Łęgowie wprowadzone przez przeora klasztoru dominikanów

${ }^{18}$ ADCh, G-71, k. 340 i 369; Kropidłowski, Z potrzeby serca, s. 245-246.

${ }^{19}$ ADCh, G-71, k. 340 i 369.

${ }^{20} \mathrm{http}$ ://www.legowo-sanktuarium.pl/content/index.php?option=com_content\&view=article \& $\mathrm{id}=69$ :otarze \& catid=43:tajemnice\&Itemid=82; dostęp z dnia 12 .02. 2011. 
gdańskich 15 sierpnia 1750 r., który przybył do parafii i przekazał dekret wystawiony w Rzymie. Jego odpis został umieszczony na początku księgi Brüderschafts-Buch bei der katholischen Pfarr Kirche zu Langenau 1854, przechowywanej w Archiwum Parafii św. Mikołaja. Czytamy w nim, że najlepszym środkiem osiągnięcia zbawienia jest modlitwa. Spośród wielu modlitw do tego celu „bardzo przyczynia się" różaniec, ponieważ w nim przywoływana jest Najświętsza Boża Rodzicielka i rozważanie jest „,ałe życie Jezusa Chrystusa ułożone w 15 tajemnicach”. Polega on na odmawianiu 150 Pozdrowień Anielskich i 15 Ojcze nasz „na wzór Psałterza Dawidowego, który nazywany jest różańcem przez Najświętszego naszego Ojca Dominika". W dekrecie tym napisano dalej, że różaniec był przez niego wymyślony i ustanowiony, a przez papieży „po kolei zaaprobowany, ze względu na pobożne wstawiennictwo Ojców naszego Zakonu, [...] wśród innych modlitw wprowadzonych w Kościele”. Dalej stwierdzono: „O co wy, umiłowani w Chrystusie, w miejscu zwanym Łęgowo, razem z czcigodnym waszym Proboszczem, zmierzający do posiadania, powiększania i zachowania wspomnianego wyżej sposobu modlitwy, o ustanowienie i określenie Bractwa Psałterza, czyli Różańca w kościele parafialnym, w miejscu zwanym Łęgowem, i ufundowania i wzniesienia dla tegoż bractwa ołtarza i kaplicy, żebyśmy wam udzielili zgody ze stosownymi uprawnieniami i przywilejami[...]. My więc przychylni waszym życzeniom i pobożnym prośbom, udzielamy zgody i możliwości obecnym pismem na mocy udzielonej nam władzy apostolskiej, żeby wspomniane bractwo założono; jednak dołączając zgodę miejscowego ordynariusza i przeora pobliskiego klasztoru naszego Zakonu".

Dalej zaznaczono, że mogą do niego należeć „wyznawcy Chrystusa obojga płci" i wyliczono przywileje i odpusty jakie otrzymają członkowie takich bractw, które odnosiły się do żywych jak i zmarłych. Wymieniono również ich obowiązki. Był to przede wszystkim udział uroczysty w nabożeństwach w święto różańca w pierwszą niedzielę października, zgodnie z dekretem papieża Grzegorza XIII, ustanowione jako dziękczynienie za zwycięstwo nad Turkami ${ }^{21}$. (Chodziło raczej o Grzegorza XV, który zezwolił na liturgiczne obchodzenie zwycięstwa pod Chocimiem 10 października 1621 r. $)^{22}$. Przede wszystkim mieli oni w niedziele i święta gromadzić się w kaplicy i odśpiewać różaniec, odmawiać go trzy razy w ciągu tygodnia, uczestniczyć w procesjach ze swoim feretronem oraz zbierać ofiary na świece do kaplicy i kościoła.

Kapelanom bractwa, którymi mieli być proboszczowie parafii, nakazał sporządzić rejestr wszystkich członków bractwa, w księdze specjalnie do tego przeznaczonej oraz błogosławić różańce, wykładać jego tajemnice i czynić „,wszystko co powinni zazwyczaj czynić bracia wyznaczeni do tego zadania" ${ }^{23}$. Zgodnie z ówczesnymi zwyczajami, założył fundację dla bractwa w kwocie 1.000 florenów, z których odsetki stanowiły stypendia mszalne za odprawianie przed ołta-

\footnotetext{
${ }^{21}$ APŁ, Brüderschafts-Buch.

${ }^{22}$ J. Warmiński, Grzegorz XV, w: Encyklopedia katolicka, t. 6, Lublin 1993, kol. 342-343.

${ }^{23}$ APŁ, Brüderschafts-Buch.
} 
rzem Matki Bożej mszy w każdą sobotę ${ }^{24}$.

Odnośnie kaplicy postanowiono: „Pragniemy i rozkazujemy, by we wspomnianej kaplicy namalowano obraz z 15 tajemnicami naszego Odkupienia [...] oraz w tym samym obrazie wizerunek godny czci św. Dominika [...] otrzymującego na klęczkach z ręki Bożej Rodzicielki Dziewicy różańce modlitewne”. Obraz taki umieszczono w bocznym ołtarzu w kościele w Łęgowie.

Dalej postanowiono nadać bractwu wszystkie odpusty ustanowione i przypomniane w breve papieża Pawła V wydanym 20 września 1608 r. i przez Innocentego XI zestawione w breve z dnia 13 lipca 1679 r. Dodano jednak, że gdyby w przyszłości bractwo zdołało ufundować własny kościół i przenieść się z kaplicy położonej w kościele parafialnym do własnej świątyni, wtedy wszystkie te uprawnienia zostaną przeniesione do nowej siedziby bractwa ${ }^{25}$.

Zgodnie z życzeniem władz generalnych dominikanów o. Iwo uzyskał dla bractwa drugi dokument, dekret bpa Czapskiego, który m. in. postanowił: „uważam za rzecz właściwą, danie i wyrażenie zgody na ustanowienie i powstanie Bractwa Najświętszej Maryi Panny Różańca św. oraz Najświętszego i Najdoskonalszego Imienia Jezus w kościele w Łęgowie w diecezji Pomorskiej. My nakazujemy, jak też dopuszczamy, dajemy i zezwalamy na powołanie i wprowadzenie bractwa Różańca św., aby dążyło do wzrostu kultu wierzących w Chrystusa, pobudzało lud do nabożności, aby potwierdzało cytowany dokument we wszystkich punktach, klauzulach, artykułach, załącznikach i wszelkich zamierzeniach i dostarczało Ojcowskiej łaskawości fundatorowi, opiekunowi, obrońcy i wszystkim braciom i siostrom różańcowym. Na wiarę których nadane w Gdańsku 13 lipca, poniedziałek, 1750 r."26

Niestety nie wiemy ilu członków liczyło to bractwo za czasów I. Rohwedera. Po stu latach, w 1854 r. należało do niego 35 braci i sióstr z Łęgowa, Skowarcza i Różyn, a do 6 października 1887 r. zapisało się aż 189 osób, ale część z nich zmarła $^{27}$.

W nawie tej, nazywanej też kaplicą różańcową, pod jakimś zamknięciem, ustawił dwustronny feretron maryjny z obrazem Matki Bożej namalowany na wzór cudownego obrazu z Łąk, a z drugiej strony obraz Matki Bożej z Jezusem, srebrny i pozłacany. Posiadał on cztery własne cynowe świeczniki. Natomiast późniejszy proboszcz Placyd Werner (1772-1774) ufundował z własnych dochodów jeszcze dwa następne srebrne świeczniki, które zawsze miały stać przy tym feretronie $^{28}$. Zapewne był to feretron, który według relacji ks. I. Narzymskiego był przechowywany w zakrystii przez poprzednich proboszczów, w tym również ks. K. S. Boryszewskiego.

Ale I. Rohweder odnowił go i kazał przyozdobić pozłacanymi i posrebrzanymi balaszkami. Posiadał on własne małe tabernakulum w kształcie ołtarzyka. Mo-

${ }^{24}$ Z. Iwicki, Konwent oliwski (1186-1831). Leksykon biograficzny i nie tylko, Gdańsk-Pelplin 2010 dz. cyt., s. 413.

${ }^{25}$ APŁ, Brüderschafts-Buch.

${ }^{26}$ ADCh, G-71, k. 369-370; Kropidłowski, Z potrzeby serca, s. 247.

${ }^{27}$ APŁ, Brüderschafts-Buch.

${ }^{28}$ ADCh, G-71, k. 370v. 
gło się nim opiekować bractwo siedmiu boleści Najświętszej Marii Panny, kótre prawdopodobnie zostało powołane przez któregoś z poprzedników J. Rohwedera. Było nazywane też bractwem Matki Bożej Bolesnej.

$\mathrm{W}$ nawie tej bractwo różancowe przechowywało swoją wielką chorągiew z frędzlami i srebrnymi galonami oraz owalny malowany na cynie symbol bracki używany głównie w czasie pogrzebów braci ${ }^{29}$. Zapewne nawiązywał on do portretów trumiennych ${ }^{30}$ i plakietek pogrzebowych używanych przez korporacje rzemieślnicze ${ }^{31}$, które stawiano przed trumną zmarłego brata w czasie liturgii żałobnej. Tymczasem była ona przedstawiana jako tarcza procesyjna na wystawie „Przeraźliwe echo trąby żałosnej do wieczności wzywającej. Śmierć w kulturze dawnej Polski od Średniowiecza do końca XVIII wieku", która odbywała się na Zamku Królewskim w Warszawie w dniach 15.12.2000 - 15.03.2001 r. pod kierunkiem P. Morozowskiego. Obraz na awersie przedstawia Matkę Boską z Dzieciątkiem wręczającą aniołowi różaniec. Poniżej - czyściec, skąd anioł unosi duszę. Wyżej - grupa modlących się członków bractwa różańcowego. Malowidło przypomina o potrzebie modlitwy różańcowej za zmarłych, nazywanej łańcuchem łączącym ziemię z niebem. Kompozycja jest uproszczoną wersją miedziorytu braci Klauberów i Goeza Gotfryda Berna S. Maria de Consolatione. Na odwrocie jest scena dobrej śmierci, wzorowana także na miedziorycie braci Klauberów, pochodzącym z cyklu ilustrującego wybrane święta roku liturgicznego Intentiones ad Breviarii vel Officii horas In variis festis per annum. Na dole umierający w łożu. U wezgłowia - klepsydra, w nogach - diabeł zakradający się po duszę konającego. Ponad nim Chrystus rozpięty na krzyżu, u którego stóp klęczy Matka Boska trzymająca serce przebite siedmioma mieczami, symbolizującymi siedem boleści. Przedstawienie nawiązuje do rozpowszechnionego na Pomorzu typu ikonograficznego Piety. Matka Boska wskazuje prawą ręką na anioła stróża. Przedstawiono tu więc trzy osoby najważniejsze dla zbawienia duszy: Chrystusa - Odkupiciela, Marię - Współodkupicielkę i anioła opiekującego się człowiekiem za życia, duszą zaś po śmierci. Zdaniem Krystyny Moisan-Jabłońskiej, obraz z Łęgowa jest jedynym polskim przykładem połączenia sceny dobrej śmierci z przedstawieniem czyśćca $^{32}$.

Chrzcielnice ustawił przed prezbiterium. Została ona wykonana $\mathrm{z}$ drewna, pomalowana i pozłocona. Otoczył ją ozdobna kratą z dobrym zamknięciem. W niej przechowywano wodę święconą w cynowej misie.

Po prawej stronie prezbiterium wzniósł ambonę piękną w formie, ozdobioną różnymi pozłacanymi ornamentami.

Na ścianach świątyni powiesił obrazy świętych, różnej wielkości i różnych kształtów, również okrągłe, oprawione w ozdobne i pozłacane ramy, częściowo

${ }^{29}$ Tamże, k. 370v.

${ }^{30}$ Por. T. Chrzanowski, Portret staropolski, Warszawa 1995.

31 Por. Z. Kropidłowski, Samopomoc w korporacjach rzemieślniczych Gdańska, Torunia i Elblaga (XIV-XVIII w.), Gdańsk 1997, fot. 5.

${ }^{32}$ Przeraźliwe echo trąby żałosnej do wieczności wzywającej. Śmierć w kulturze dawnej Polski od Średniowiecza do końca XVIII wieku. Katalog z wystawy pod kierunkiem i redakcją P. Morozowskiego, Warszawa 2000, s. 128. 
przeniesione ze starego budynku. Na środku nawy głównej, ale nieco z tyłu kościoła, powiesił barwną i pozłacaną rzeźbę anioła, który dzierży w dłoniach krucyfiks, tak aby każdy wchodząc do niej musiał na niego spojrzeć. Miejsce to może mieć też znaczenie symboliczne, bo jest związane z jego grobem, który dla siebie przygotował u wejścia do świątyni.

Płaski sufit świątyni wykonano z drewna, który kazał pomalować w formie firmamentu niebieskiego ze złotymi gwiazdami wśród których wyróżniało się 5 większych gwiazd i 2 cynowe bębenki oraz jedna para trąb.

Chór z drewna rozciągnął na całą szerokość nawy, a na nim zamontował organy. Może to był dawny pozytyw, który przyozdobił prospektem pomalowanym i pozłoconym. Na chórze umieścił też ławy dla komorników wiejskich.

Po środku świątyni, dla wygody parafian, ustawił 2 rzędy jednakowych, pomalowanych ławek. Dodatkowo w nawie, przed ołtarzem św. Bernarda, ustawił cztery ławki, a w prawej jedną ławkę. W prezbiterium, dla kapłanów, witrykusów i służby kościelnej, ustawił dwie ławki. Po obu stronach prezbiterium, we wnękach muru, kazał wykonać szafki, mocne posiadające dobre zamknięcia.

Posadzkę wykonano z płyt kamiennych i marmurowych. I. Rohweder wznosząc budynek nowej świątyni zachował dawny grobowiec z płytą zawierającą inskrypcję: „Tu leży Berchard Badach proboszcz klasztoru w Oliwie pochowany 6 maja 1622 r." "33 Trudno dzisiaj jest powiedzieć coś więcej o nim, ponieważ nawet ks. Zygmunt Iwicki, badacz dziejów tegoż klasztoru, nie wymienia ks. B. Badacha wśród grona zakonników. Znany jest mu jedynie konwers Jan Badach zmarły 2 grudnia 1624 r. który był malarzem ${ }^{34}$.

Pewne jest natomiast, że I. Rohweder wymurował pośrodku kościoła kryptę grobową, do której schodziło się po kamiennych schodach, którą przykrył płytą kamienną z inskrypcją łacińską: „Arką, którą uniósł wymowny Noe, on sam nakrył pobożne duchy, dopóki wstają położył ojciec Iwo Rohweder, przeor Zakonu Cystersów w Oliwie, doktor św. teologii, sekretarz prowincjalny, proboszcz w Łegowie i Różynach w 1748 r." "35

W późniejszym czasie pochowano w kościele jeszcze jednego proboszcza, nad grobem którego w nawie bocznej przy ołtarzu różańcowym umieszczono płytę z napisem: „Znakomity czcigodny pan ojciec Placid Werner ,proboszcz w Łęgowie i Różynach, mnich oliwski ze świętego zakonu Cystersów, doktor teologii i obojga praw, notariusz apostolski, zmarły 19 lutego 1774 r. Niech spoczywa w pokoju" 36 . Był on proboszczem łęgowskim i różyńskim tylko przez dwa lata, bo 24 stycznia 1772 r. został instytuowany, a zmarł 13 lutego 1774 r. (jest różnica $\mathrm{w}$ dacie śmierci, może kamieniarz się pomylił) w Łęgowie ${ }^{37}$. W swoim testamencie ufundował w klasztorze oliwskim mszę rocznicową z ugoszczeniem konwentu oraz taką mszę w kościele parafialnym w Oliwie, Łęgowie i Różynach. Z rocz-

${ }^{33}$ ADCh, G-71, k. 369.

${ }^{34}$ Iwicki, Konwent oliwski (1186-1831), s. 488.

${ }^{35}$ ADCh, G-71, k. 369.

${ }^{36}$ Tamże; Kropidłowski, Z potrzeby serca, s. 248.

${ }^{37}$ Nowicki, Słownik biograficzny rządców parafii archidiakonatu pomorskiego, s. 225; Iwicki, Konwent oliwski (1186-1831), s. 470-471. 
nych procentów w każdym kościele celebrans miał otrzymać 2 floreny, organista 18 gr, sługa kościelny kalikujący „zwyczajną opłatę”, a resztę ubodzy ${ }^{38}$.

Natomiast dla siebie samego I. Rohweder, na znak wielkiej pokory, przygotował grobowiec w wejściu do świątyni, którą umieścił, tak aby nad jego ciałem musieli przechodzić wszyscy do niej wstępujący, a jego zwłoki będą spoglądały na zwieszony krucyfiks podtrzymywany, jak gdyby dla niego, przez anioła. Na płycie nagrobnej napisano: „Tu ukryte są kości grzesznika , Ojca Iwo Rowedera, Przeora Oliwy, Świętego Zakonu Cystersów, Prepozyta w Łęgowie i Różynach, Doktora Teologii, Notariusza Apostolskiego, złożone 1765 roku, dnia 29 miesiąca maja. W wieku 65 lat tu spoczywa a także milczy niegdyś pobożny orator" (tłumaczenie ks. Z. Iwickiego) ${ }^{39}$.

Zakrystię kazał o. Iwo wznieść na nowym miejscu, za głównym ołtarzem, zdwoma wejściami, jednym z kościoła, a drugim z cmentarza. Oba zostały wyposażone w solidne drzwi z mocnymi zamkami. Została ona zasklepiona łukiem murowanym. W zakrystii umieścił szafy do przechowywania sprzętów i szat liturgicznych, stół i dwie skrzynki. Pierwszą do przechowywania Najświętszego Sakramentu w Wielki Piątek, a drugą do olejów św. W okna zakrystii kazał wmurować żelazne solidne kraty.

Do świątyni prowadzą dwa portyki o formach barokowych, główny większy nieco ozdobny, na przedłużeniu nawy i mniejszy od strony prawej, przez który były $\mathrm{m}$. in. wnoszone niemowlęta do chrztu św. i wprowadzane kobiety po porodzie w ramach ceremoniału tzw. wywodu. Wejścia zaopatrzył w drzwi mocne, z solidnymi zamkami. Zapewne wykorzystał drzwi przygotowane przez swojego poprzednika.

Ponieważ kościół i cmentarz położone były na niewielkim wzgórzu, dlatego wejście na cmentarz poprowadził przez duże drewniane bramy, dalej po drewnianych schodach do głównego wejścia, przed którym było jeszcze pięć stopni kamiennych zaopatrzonych $\mathrm{w}$ poręcze.

O. I. Rohweder wyposażył świątynię w cenne wyposażenie. Przede wszystkim podarował srebrną monstrancję, którą kazał przyozdobić cennymi pierścieniami i klejnotami oraz 6 srebrnych świeczników, wspomniane już tabernakulum kunsztownie zdobione elementami pozłacanymi i posrebrzanymi, duży srebrny krucyfiks, pozłacane świeczniki w kształcie ramion. Dalej ofiarował jeszcze kropidło, kadzielnicę, łódkę na kadzidło, dwie pary ampułek. Pierwsza para była szklana ze srebrną tacką, a druga metalowa, pozłacana oraz misę na wodę święconą i srebrne małe naczynie na oleje święte i drugie do roznoszenia Najświętszego Sakramentu do chorych.

Ufundował również cenny baldachim procesyjny, który był obszyty jedwabiem i przyozdobiony srebrnymi frędzlami.

W kościele kazał powiesić przed głównym ołtarzem ufundowany przez siebie żyrandol wykonany z mosiądzu, ale pozłacany i posrebrzany. Dla ołtarza głównego ufundował trzy różne zasłony - antepedia. Pierwsze wizytator określił jako

\footnotetext{
${ }^{38}$ Iwicki, Konwent oliwski (1186-1831), s. 471.

${ }^{39}$ Tamże, s. 415.
} 
różnokolorowe, drugie jedwabne z koronkami, a trzecie wykonane ze skóry angielskiej, czyli był to kurdyban zachowany do dziś. Natomiast w ołtarzach bocznych były tylko antepedia kurdynabowe. Nadto ufundował także krucyfiks do procesji oraz figurkę Zmartwychwstałego $\mathrm{z}$ chorągiewką na procesje paschalne. Ołtarze boczne zaopatrzył w krucyfiksy stojące w miejscach tabernakulów, nieco mniejsze. Na pierwszym była pasyjka z mosiądzu, na drugim ze szkła kryształowego, a na trzecim drewniana. Wszystkie te krzyże miały marmurowe podstawy. Kościół posiadał też figurę Chrystusa na krzyżu, którą wystawiano tylko w czasie Triduum Paschalnego. W spisie inwentarza w 1765 r. odnotowano również różaniec.

Rohweder ufundował również cały zestaw świeczników, sześć cynowych na ołtarz główny, sześć mosiężnych, cztery ustawione przy feretronie Matki Bożej, dwa cynowe na ołtarz Ukrzyżowania oraz cztery małe z mosiądzu. Nadto w celu godnego roznoszenia wiatyku do chorych oraz dla uszanowania Najświętszego Sakramentu w czasie uroczystych procesji kazał wykonać cztery latarnie z „białej” blachy za szkiełkami. Oprócz tego ufundował komplet pacyfikałów: cynowy pozłacany, mosiężny pozłacany i żelazny. O autentyczności relikwi w nich przechowywanych wizytator ks. B. Trochowski milczy. Na kwiaty do świątyni przeznaczył cztery dzbany cynowe i cztery szklane.

Za własne pieniądze I. Rohweder zakupił liczne naczynia i szaty mszalne oraz stroje liturgiczne. Były to dwie puszki do przechowywania Najświętszego Sakramentu w tabernakulum, pierwsza srebrna w środku pozłacana, druga mosiężna i też wewnątrz pozłacana. Do tego 5 srebrnych kielichów pozłacanych wewnątrz i na zewnątrz i dwa pozłacane tylko wewnątrz. $Z$ szat liturgiczny wizytator wymienił czternaście alb, w tym jedna była z szeroką srebrną koronką, druga obszyta kolorową tkaniną jedwabną z żółtą koronką, dwie z białą koronką podszyte jedwabiem, dwie podszyte czerwonym i dwie podszyte niebieskim jedwabiem. Dla ministrantów służących w procesjach i noszących kadzielnicę i baldachim, ufundował ozdobne komże, a innym jeszcze dziewiętnaście komż, $w$ tym pięć świątecznych z koronkami. Kierownikowi szkoły, który spełniał wtedy rolę ceremoniarza, dostojny płaszcz.

Fundator ten polecił również uszyć piętnaście korporałów, w tym jeden obszyty był jedwabną czerwonozłotą koronką, jeden złotą, dwa czarną do mszy pogrzebowych. Pozostałe były zwykłe. Do tego doszło jeszcze sześć obrusów ołtarzowych wykonanych z różnych tkanin, osiem pasków kapłańskich, dziesięć większych i jedenaście mniejszych ręczników i puryfikaterzy, piętnaście humerałów, trzynaście welonów na kielichy, jedną albę z wyhaftowanymi kwiatami i złotą koronką, jedną z wymalowanymi na jedwabiu srebrnymi kwiatami, jedną obszytą złotą koronką, jedną do niebieskich maryjnych szat ze srebrną koronką, dwie do czarnych szat ze srebrną koronką, a pozostałe zostały określone jako „świąteczne”.

Ufundował jeszcze wiele paramentów mniej cennych, które w czasie nie każdej wizytacji były opisywane, ale były ważne dla codziennej liturgii. Było to flexorium, cztery cynowe miseczki, z których trzy były przeznaczone na wodę święconą, dwie ustawione przy wejściach, a jedna w zakrystii. Nabył również mosięż- 
ną kadzielnicę i cynową nawikułę, siedem par ampułek z czterema talerzykami, cztery czarne birety, jeden czarny kir pogrzebowy i jeden niebieski, zapewne dla okrywania trumny zmarłych członków bractwa różańcowego, trzy dzwonki, które przymocowano do ścian kościoła przy ołtarzach bocznych, sześć dzwonków na procesję, komplet chorągwi, w tym cztery czerwone, cztery niebieskie i dwie czarne oraz dwa bębny cynowe i parę trąb. W zakrystii przechowywano również żelazną formę do wypiekania pojedynczych hostii i opłatków z dwoma kamiennymi naczyniami do ich przygotowywania. W zakrystii w czasie wizytacji w $1765 \mathrm{r}$. były dwa malowidła, Grobu Pańskiego na Wielki Piątek i ciemnicy na Wielki Czwartek, które przypisano również fundacji I. Rohwedera.

W kościele w tym czasie były dwie skarbony. Pierwsza żelazna została ustawiona $\mathrm{w}$ świątyni, a druga $\mathrm{z}$ drewna dębowego została przymocowana do ściany w zakrystii.

Zakupił również komplet ksiąg liturgicznych, z których w 1765 r. wymieniono cztery mszały. Pierwszy z nich był cenny, przyozdobiony odlanymi ze złota figurkami i posiadał „zamknięcie”. Drugi był oprawiony w srebrne blachy i też miał „zamknięcie”. Pozostałe zostały określone jako „zwyczajne”. Poza tym nabył dwa ewangeliarze, jeden w języku polskim, drugi w niemieckim, rytuał $i$ agendę liturgiczną.

W protokole powizytacyjnym z $1765 \mathrm{r}$. nie wspomniano nic o obrazach i relikwiach oraz działalności bractwa różańcowego i fundacjach mszalnych. Dopiero w 1781 r. odnotowano, że na ścianach świątyni wisiały obrazy, które mogły być przeniesione ze starego kościoła, ale część z nich mogła pochodzić z fundacji I. Rochwedera. Na pierwszym miejscu wymieniono dwa owalne przedstawiające Pokłon Trzech Króli i Chrzest Pana Jezusa, dwa kwadratowe przedstawiały postać św. Józefa i św. Bernarda, a były umieszczone w rzeźbionych i pozłacanych ramach, dalej św. Bernarda i św. Jana Nepomucena, a także św. Floriana i św. Barbary. W prezbiterium wisiał obraz z różnymi niepotwierdzonymi relikwiami przeplatanymi złotymi, srebrnymi i wykonanymi z jedwabiu kwiatami oraz obraz przedstawiający Baranka Bożego umieszczony za szkłem. Były również nieliczne wota: do feretronu przymocowano pięć serc i dwie stopy oraz serce przy ołtarzu Ukrzyżowania.

W 1781 r. wizytator odnotował, że w kościele tym nie było, żadnych obrazów uznanych za cudowne", ani namalowanych w formie niestosownej do wymagań Kościoła. Były one umieszczone w miejscach ,godnych” i nie narażone na zniszczenie. Większość z obrazów była dodatkowo przyozdobiona blaszkami srebrnymi, pozłacanymi, posrebrzanymi, stosownie do ówczesnej sztuki zdobniczej, ale nie było na to zgody władz kościelnych.

W 1781 r. podkreślono również, że w kościele tym przechowywano wiele relikwi, ale wszystkie miały wątpliwe pochodzenie i nie posiadały dokumentów stwierdzających ich autentyczność. Nie zgadza się to z księgą odpisów protokołów powizytacyjnych, z której wynika, że autentyczność relikwii Krzyża św. potwierdza dokument z 16 lipca 1736 r. wystawiony przez dominikanina i biskupa Antaniusa Seraphinusa Gamarda, który stwierdza, że „w kościele jest cząstka Krzyża Świętego, oprawiona w mały pacyfikał" o numerze relikwii C/3 oraz po- 
daje uroczyście, że zezwala na oddawanie publicznej czci tym relikwiom ${ }^{40}$. Znajdowały się one w małym relikwiarzu ustawionym na ołtarzu Krzyża św., w północnej części transeptu.

W parafii obchodzono dwa odpusty parafialne, na święto św. Mikołaja Biskupa i we Wniebowzięcie Najświętszej Marii Panny, kiedy to za nawiedzenie kościoła i zmówienie wyznaczonych modlitw prepozyt miał prawo udzielać odpustu 10 letniego. O. I. Rohweder uzyskała dla bractwa różańcowego odpust, którego warunki kazał wypisać i umieścić na tablicy w ołtarzu brackim.. O. I. Rohweder, jego następcy i wikariusze parafii mieli prawo udzielania odpustów zupełnych konającym.

Ustanowił on również jedną fundację, która polegała na tym, że z własnych funduszy oddał na procent 1000 florenów panu Alexowi Marlino, zamieszkującemu w Hoppenbruch pod Gdańskiem. On i jego spadkobiercy mieli przekazywać każdego roku 50 florenów na odprawianie mszy przy ołtarzu Matki Bożej w pierwszy dzień tygodnia przez cały rok ${ }^{41}$.

Można przypuszczać, że fundacja ta łączyła się z bractwem siedmiu boleści Najświętszej Marii Panny, którego erekcję uzyskał w Rzymie 8 kwietnia 1745 r., a w parafii zostało wprowadzone w następnym roku. Jego celem było świadczenie dzieł miłości i miłosierdzia oraz pogłębianie prywatnej pobożności członków. Przede wszystkim wymagano od nich, aby przybyli do świątyni, wyspowiadali się i przyjęli komunię w czasie Eucharystii w święto brackie, które sami sobie wybiorą po Wielkanocy i uzyskają na nie aprobatę biskupa ordynariusza. Święta tego nie było im wolno samowolnie zmieniać. W czasie nawiedzenia kościoła mieli modlić się za Kościół św., „,wycięcie” herezji, o nawrócenie heretyków i niewiernych, o pokój między książętami chrześcijańskimi, o zgodę i jedność między chrześcijanami, o zdrowie dla żyjącego ówcześnie papieża. Za to papież udzielił im przywileju odpustu zupełnego.

Oprócz tego mieli przybywać do świątyni parafialnej w cztery inne święta, także przez bractwo wybrane i zaaprobowane przez biskupa, aby uczestniczyli w Eucharystii, procesjach oraz innych nabożeństwach i zanosili modlitwy w tych intencjach, za co otrzymają siedem lat i czterdzieści dni odpustu.

Natomiast za uczynki miłosierdzia, które zostały dokładnie wymienione mogli otrzymać 60 dni odpustu. Było to grzebanie zmarłych, asystowanie kapłanowi udającemu się z wiatykiem do chorego albo przyklęknięcie przed tym kapłanem i odmówienie raz Modlitwy Pańskiej za chorego, do którego udawał się kapłan. Od braci wymagano także przyjmowania wędrowców do swojego domu w gościnę i udzielenia im jałmużny, odwiedzania chorych i pocieszania ich w trudnych sytuacjach oraz pouczania ich o warunkach zbawienia. Odpust tem można było uzyskać również za nauczanie przykazań Bożych, a szczególnie za sprowadzenie kogoś zbłąkanego na drogę zbawienia, za pojednanie się z nieprzyjaciółmi własnymi i wprowadzenie pokoju między innymi osobami zwaśnionymi oraz za odmówienie pięć razy Ojcze nasz i Zdrowaś za dusze współbraci zmarłych

\footnotetext{
40 APŁ, Chronika Parochia Łęgowo, s. 42.

${ }^{41}$ ADCh, G-71, k. 369-370; Kropidłowski, Z potrzeby serca, s. 252.
} 
O. I. Rohweder, poza ufundowaniem nowej świątyni i troską o wysoki poziom duszpasterstwa w parafii, zatroszczył się o zapewnienie jej podstaw materialnych i dochodów. Wspomniano już, że parafia posiadała niewielkie beneficjum, bo stanowiło ono tylko 2 łany gruntów, z których lepszą częścią były łąki. Na pozostałych gruntach wysiewano rocznie 32 korce pszenicy, które w $1741 \mathrm{r}$. warte były 151 florenów (czyli korzec kosztował 4 floreny i 21 groszy). Jako daninę z tytułu dziesięciny otrzymywał on jako proboszcz 47 korców pszenicy i tyleż owsa ze wsi Łęgowo. Nadto opłatę 17 florenów na zakup drewna opałowego i tyle samo na kolędę. Jesienią od każdego gospodarza 15 główek kapusty, a na Wielkanoc 15 jaj i pierwszy chleb z każdego chłopskiego wypieku.

Ze wsi Grabiny, jako dziesięcinę, otrzymywał 24 korce jęczmienia albo w zamian ekwiwalent pieniężny w wysokości 30 florenów. Na kolędę 36 florenów oraz jarzyny i jaja. Ze Skowarcza otrzymywał jako dziesięcinę po 20 korców pszenicy i owsa, na zakup drewna opałowego rocznie 8 florenów, na kolędę 16 florenów i 18 groszy, również chleb, 15 jaj i tyleż samo główek kapusty od każdego gbura. W sumie było to znacznie mniej niż pobierali proboszczowie w parafiach diecezjalnych. Razem było to po 67 korców pszenicy i owsa, 24 korce jęczmienia, 94 floreny i 18 groszy oraz chleb, kapustę, warzywa i jaja.

Być może dlatego o. Iwo, dla zwiększenia dochodów parafii zbudował za kościołem, na piaszczystej ziemi, 4 chaty i 5 nieco oddalonych od kościoła, by przynosily roczny dochód z czynszów w kwocie 15 florenów każda, czyli razem 135 florenów. Ponadto wzniósł w pobliżu przytułka piec piekarski, który miał służyć wszystkim mieszkańcom Łęgowa, ale za to z każdego wypieku należało ofiarować po jednej kromce chleba dla pensjonariuszy przytułku. Założył również ogród na dotychczasowym nieużytku, ogrodził go i nakazał uprawiać pensjonariuszom dla swoich potrzeb.

Na utrzymanie przytułka przeprowadził zbiórkę i zgromadzoną kwotę w wysokości 500 florenów pożyczył na procent Janowi Rentz, a drugą, 200 florenów, powierzył gospodarzowi Godfrydowi Gerlachowi z Łęgowa, by nimi dobrze zarządzali i aby ,przynosiły godne dochody na utrzymanie przytułku”"42.

O. I. Rohweder wzniósł również szkołę parafialną, z drzewa ofiarowanego przez klasztor oliwski oraz wykorzystał drewno pozostałe z rozbiórki ze starego kościoła. Utrzymywali ją mieszkańcy Łęgowa i Skowarcza. Zamieszkał w niej organista, który był również nazwany „kierownikiem szkoły”. Jego utrzymanie stanowiły ofiary ze wsi Łęgowo w wysokości 17 korców pszenicy i chleb z pierwszych wypieków oraz od każdego kmiecia 15 główek kapusty, 15 jaj i 17 florenów rocznie na drewno opałowe od całej wsi. Od mieszkańców Skowarcza otrzymywał 9,5 korca pszenicy, na kolędę 16 florenów, jaja, jarzyny i chleb oraz od każdego gbura 4 grosze na kwartał. W 1781 r. z Łęgowa uczęszczało do tej szkoły 40 chłopców, a ze Skowarcza 20. Natomiast ze wsi Grabiny nic nie otrzymywał i nie odnotowano, aby z niej uczęszczały do tej szkoły jakieś dzieci.

Przytułek został wzniesiony z drewna pochodzącego z rozbiórki starej świątyni oraz z sosen dostarczonych z lasów klasztoru oliwskiego, które przyznał opat

${ }^{42}$ ADCh, G-71, k. 375; Kropidłowski, Z potrzeby serca, s. 253. 
Józef Jacek Rybińki mocą specjalnego dekretu. Przytułek (xenhondium) był niewielki, ale zapewne dostosowany do potrzeb. Przeznaczony był dla trzech parafian obojga płci, a czwarte miejsce było rezerwowane dla niespodziewanych podróżnych, którzy „w drodze mogą zostać zaskoczeni nagłą chorobą, mianowicie ile razy zdarzy się, że podróżny z powodu nagłej ciężkiej choroby upadnie na drodze (jeśli nie cierpi na jakąś zakaźną chorobę, albo z innej wsi nie zostanie podrzucony), łaskawie i troskliwie będzie traktowany, dopóki nie odzyska sił, albo stęskniony zapragnie powrócić do swego domu"43.

Dla pensjonariuszy przeznaczył nieużytek o długości 10 i szerokości 7 prętów, który leżał na prawo od świątyni, w sąsiedztwie „większej gospody”, na którym urządził ogród.

Oprócz pensjonariuszy mieszkała w nim pewna kobieta, która prowadziła szkołę dla dziewcząt ucząc je podstaw wiary, czytania, sztuki przędzenia i tkania. Była opłacana przez rodziców, którzy posyłali do niej swoje córki. Zapewne opiekowała się także chorymi. Mieszkańcy Łęgowa na prośbę o. Iwo, z własnej woli, zobowiązali się dostarczać pensjonariuszom, jako jałmużnę, rocznie trzy i ćwierć korca, mieszkańcy Skowarcza cztery, a Grabiny trzy i pół korca pszenicy. W interesie parafian przebudował dawny piec do wypiekania cegieł, na piec chlebowy, ale postanowił, że część z wypieków nazwana „okruchy”, miała być przeznaczana na rzecz pensjonariuszy. Ustawił również przed wejściem do przytułka skarbonkę, do której przechodnie mogli wrzucać ofiary na ich rzecz, a gdyby przymusiła by ich bieda, zezwolił na zbieranie jałmużny od drzwi do drzwi w całej parafii. W końcu ofiarował im i pozwolił na wspólne chowanie jednej krowy i dwóch wieprzów i darmowe wypasanie ich na łąkach gminnych do kiedy nie będą mogli za to płacić. Aby te uprawnienia przetrwały jego działalność w parafii wydał dokument $\mathrm{w}$ formie dekretu, w którym wezwał swoich następców, aby roztaczali opiekę nad ubogimi i nad tym pobożnym dziełem. Wydał go 5 maja 1749 r., a jego odpis znajduje się w Archiwum Parafialnym ${ }^{44}$

We wsi Grabiny, zamieszkałej w większości przez ewangelików, funkcjonowała prywatna kaplica, utrzymywana w tym celu, aby w czasie wylewu rzeki, która oddzielała ją od kościoła parafialnego, można było tam chrzcić dzieci. Wolno przypuszczać, że i ją ufundował o. I. Rohweder, ponieważ jej wyposażenie pochodziło z klasztoru oliwskiego. Po I rozbiorze Polski została ona zamknięta, a sprzęty zwrócono do klasztoru ${ }^{45}$.

Działalność o. I. Rohwedera miała bardzo szeroki charakter. Dla parafii w Łęgowie ma on szczególne znaczenie. Wzniósł bowiem piękny kościół, który góruje nad wsią i okolicą. Wyposażył go w cenne i niespotykane sprzęty i paramenty liturgiczne. Zadbał również o dochody parafii i swoich następców. Był gorliwym duszpasterzem i prowadził działalność charytatywną. Związał się ze swoim dziełem i swoimi parafianami na wieki, pragnął $i$ został w świątyni łęgowskiej pochowany. Zmarł 29 maja 1765 r. w Łęgowie. Wcześniej przeznaczył aż 100 talarów pruskich na odprawianie corocznie ośmiu cichych mszy w kościele w Łęgowie za spokój jego duszy.

\footnotetext{
${ }^{43}$ Tamże; APŁ, Chronika, s. 140-141.

${ }^{44}$ Tamże, s. 140-145.

${ }^{45}$ ADCh, G-71, k. 375.
} 
W Archiwum Archidiecezji Gdańskiej zachowała się w Księdze Zgonów Parafii w Łęgowie notatka mówiąca, że „29 maja [1765 r] zmarł w rezydencji w Łęgowie, opatrzony najświętszymi sakramentami, wspaniały i wyjątkowy ojciec, wielebny Iwo Rohweder, prepozyt w Łęgowie, który przez dwadzieścia cztery lata zaszczytnie kierował tamtejszym kościołem, który postawił od fundamentów wraz z kościołem w Różynach, i Świętej Teologii Doktor, a niegdyś przez lata był przeorem w Oliwie i notariuszem apostolskim. Przeżył 65 lat i został pochowany w portyku kościoła w Łęgowie, pod dzwonnicą, w grobowcu przygotowanym dla siebie samego dziewięć lat wcześniej, do którego dodano płytę nagrobną z takim napisem"46. Został on już podany wyżej.

Można więc powiedzieć, że z parafią w Łęgowie związał się bardziej niż z klasztorem oliwskim, przecież znacznie wspanialszym. Jego praca i postawa została zauważona i wyróżniona przez biskupa Walentago Aleksandra Czapskiego, który za wiedzą opata J. Rybińskiego, postawił go za wzór dla duchowieństwa diecezjalnego i zakonnego oraz 12 lutego $1751 \mathrm{r}$. obdarował go i jego następców tytułem prepozytów ${ }^{47}$.

\section{IWO ROHWEDER (1698-1765) AS THE CHURCH BUILDER AND PARISH PRIEST IN LĘGOWO}

\section{Summary}

Iwo Rohweder was a Cistercian monk in Oliwa. He was the Prior in the monastery. Together with Jacek Rybiński, the abbot, he took an active part in major religious and political events in the Pomeranian region. He contributed greatly to raising the splendour of the monastery in its religious, cultural and economic aspect.

Between 1741-1765 he devoted himself to pastoral work in St. Nicholas church in Łęgowo. Besides his parish church he also renovated the branch church in Różyny; he built new utility buildings. Rich interior decorations were to serve pastoral purposes and conversion into Roman Catholic faith. As the parish priest he called rosary and charity fraternities to life and , caring for the poor, he funded and equipped the parish poorhouse. He was so involved with the parish that it was his wish to be buried in the church, not in the monastery.

\footnotetext{
${ }^{46}$ Cyt. za: Iwicki, Konwent oliwski (1186-1831), s. 414.

${ }^{47}$ Tamże.
} 